\title{
Evaluation of FR104, a Treg sparing antagonist anti-CD28 monovalent Fab' antibody in kidney transplantation in non-human primates
}

\author{
Nicolas Poirier ${ }^{1,2}$, Nahzli Dilek ${ }^{1,2}$, Caroline Mary ${ }^{1,2}$, Jeremy Hervouet ${ }^{1}$, David Minault ${ }^{1}$, Julien Branchereau', \\ Xavier Tillou', Stephanie Le Bas-Bernardet ${ }^{1}$, Bernard Vanhove ${ }^{1,2^{*}}$, Gilles Blancho ${ }^{1}$ \\ From 7th European Workshop on Immune-Mediated Inflammatory Diseases \\ Noordwijk aan Zee, the Netherlands. 28-30 November 2012
}

\section{Background}

Targeting CD28 costimulation with antagonist anti-CD28 antibodies has the potential to block effector $\mathrm{T}$ cells without perturbation of the CTLA-4 and PDL-1-mediated inhibitory signals important for the function of Treg cells, which might favour tolerance induction.

\section{Methods and results}

Here we evaluated in a non-human primates this "Treg sparing strategy" with FR104, a novel monovalent humanized and pegylated Fab' anti-CD28 antibody fragment. PK/PD studies in monkeys revealed that FR104 presented an elimination half-life of 8 days and $100 \%$ target saturation over at least a month after a single iv injection of $5 \mathrm{mg} / \mathrm{kg}$. FR104 was next evaluated in a baboon kidney allograft model at the dose of $5 \mathrm{mg} / \mathrm{kg}$ at day $0,4,14$ and then every two-week until 3 months. Monotherapy modestly but significantly prolonged allograft survival (MST: 18.5 days for monotherapy vs 6 days for untreated recipients). FR104 synergized with low doses tacrolimus (lowTac, trough: 5-10 ng/ml; MST $>100$ days for FR104/ lowTac vs. 15 days for lowTac alone) as well as with calcineurin-free regimens: therapeutic doses of MMF or rapamycin (day 0-90) with $1 \mathrm{mg} / \mathrm{kg}$ of corticosteroids from day 0-14 (MST >100 days for FR104 + MMF/Rapa vs. 18/15 days for MMF/Rapa alone). Flow cytometry analyses indicated that blood Treg cells of the natural and inducible types were preserved in FR104/MMF or FR104/lowTAC bitherapies and accumulated in FR104 monotherapy and in FR104/Rapa bitherapy, whereas Treg cells were lowered by MMF and lowTac monotherapies. Histology also

${ }^{1}$ Institute of Transplantation Urology Nephrology, University of Nantes, INSERM UMR 1064, Nantes, France

Full list of author information is available at the end of the article revealed that CTLA4+ and Foxp3+ T lymphocytes were accumulated into the graft of FR104 treated recipients.

\section{Conclusion}

FR104 presented Treg sparing properties in kidney transplantation and this was associated with prevention of graft rejection in synergy with tacrolimus, MMF or rapamycin.

\section{Author details}

${ }^{1}$ Institute of Transplantation Urology Nephrology, University of Nantes, INSERM UMR 1064, Nantes, France. ${ }^{2}$ Effimune, Nantes, France CHU Nantes, Nantes, France.

Published: 28 November 2012

\section{doi:10.1186/1479-5876-10-S3-P61}

Cite this article as: Poirier et al.: Evaluation of FR104, a Treg sparing antagonist anti-CD28 monovalent Fab' antibody in kidney

transplantation in non-human primates. Journal of Translational Medicine 2012 10(Suppl 3):P61.

Submit your next manuscript to BioMed Central and take full advantage of:

- Convenient online submission

- Thorough peer review

- No space constraints or color figure charges

- Immediate publication on acceptance

- Inclusion in PubMed, CAS, Scopus and Google Scholar

- Research which is freely available for redistribution 